\title{
Drug Rehabilitation Treatment: The Consistency Practice of Remembrance to Allah (Zikir) among Drug Addicts in Malaysia
}

\author{
Fadzli Adam \\ Associate Professor, Faculty of Islamic Contemporary Studies \& Research Fellow, Research Institute for Islamic Product and \\ Civilization (INSPIRE), Universiti Sultan Zainal Abidin (UniSZA) \\ fadzliadam@unisza.edu.my
}

\section{Wan Ibrahim Bin Wan Ahmad}

Associate Professor, College of Arts and Sciences, Universiti Utara Malaysia wiwa@uum.edu.my

\section{Marhana Mohammed Anuar}

Senior Lecturer, School of Maritime Business and Management, Universiti Malaysia Terengganu marhana@umt.edu.my

Asyraf Ab Rahman

Associate Professor, Centre for Foundation and Liberal Studies, Universiti Malaysia Terengganu asyraf@umt.edu.my

\section{Doi:10.5901/mjss.2015.v6n2s1p336}

\section{Abstract}

Various forms of treatment and rehabilitation, either traditional or spiritual, introduced to solve the problem of drug addiction among the youths in Malaysia. Remembrance to Allah (zikir) has been identified to give a positive effect in the drug rehabilitation process. This study aims to analyze the consistency levels of remembrance to Allah either aloud (jahar) and silent (khafi) remembrance between former drug addicts and relapse in the process of drug rehabilitation treatment in Malaysia. The data of the study is collected through quantitative and qualitative methods. A total of 60 people, 30 people are former addicts in Terengganu and 30 people are relapsed drug addicts under rehabilitation at Pondok Remaja Inabah rehabilitation centre (PRI) in Kedah and Terengganu, Malaysia are chosen as the respondent for survey procedure. In addition, there are also 10 key informants selected from these respondents for in depth interview procedure. Survey and structured interview data are analyzed using triangulation methods. The results show significant difference between the two groups in relation to consistency practice of remembrance to Allah. Former drug addicts show more consistency in the practice of remembrance comparing to relapsed drug addicts. Therefore, the level of consistency is seen as an important contributing factor to prevent individuals from drug addiction.

Keywords: Islam; Remembrance to Allah: Zikir; Spiritual and Traditional; Drug Rehabilitation

\section{Introduction}

A synergy effort has been taken by Malaysian government and non-government agencies to enhance rehabilitation process by establishing many rehabilitation centres across the country. Spiritual-based approach is becoming regularly method for treating a variety of illness including drug addiction. In Malaysia, spiritual-based approach is regarded as a widely accepted method of treatment and commonly practised either in Islam and Christianity to treat various diseases including drug addiction. Among alternative drug treatment and rehabilitation modalities are Raden Suratman's Traditional and Spiritual Drug Addiction Rehabilitation, Darul Syifa's Spiritual Drug Addiction Rehabilitation, Hj. Salleh's Traditional and Spiritual Drug Addiction Rehabilitation, Jabat Sufi's Private Drug Treatment \& Rehabilitation, Christianity Spiritual Drug Addiction Rehabilitation, and Malaysian Association for the Study of Traditional Asian Medicine (MASTAM) (Adam, 2011).

In addition, non-government agencies have set up rehabilitation institutions with a variety of methods to combat the 
drug problem. Cold turkey, acupuncture, nutritional replacement and rationing, psychotherapy and religious approach are among methods introduced to treat drug addiction. Moreover, many private drug rehabilitation centres, which are traditionally practised by the medicine men or shamans, have been established since 1977 (Rohana, 1994). Two thousand medicine men are reported working on the fulltime basis and 20,000 more on a part-time basis (Spencer dan Navaratnam, 1981). The high percentage of spiritual involvement in drug rehabilitation indicates the effectiveness of this approach in treating the problem.

\section{Literature Review: Drug Addiction Rehabilitation and Treatment}

The establishment of rehabilitation centre as a way of drug treatment and rehabilitation is in reality not of something that society can be proud of. Relapsed drug addicts that are reported by AADK prove the fact that the ongoing rehabilitation process is far from satisfying. The number of healed drug addicts after participating in treatment and rehabilitation program, is so small compared to relapse. Wan Mahmood Pawanteh (1998) reported that $90 \%$ out of 100 drug addicts are relapsing within five years of drug rehabilitation and treatment program. The finding from the Ministry of Community Welfare (Chuah, 1990) reported that only $37 \%$ of the former drug addicts are totally cured and be self-sufficient whereas the rest return to drug addiction. This phenomenon raises a question mark about the effectiveness of the available rehabilitation centre in dealing with this social problem (Jamaluddin, Mohd. Khairie, Zaheruddin \& Subri, 2000).

The situation is intensely worrying as drug has become a source of HIV spread. Since the first case of HIV infection among drug addicts is detected in Malaysia, a total of 23,547 HIV infections have been detected between October 1988 and 1999 where 76\% of them are drug addicts. In Terengganu alone, 3,741 (70\%) out of 5,348 HIV infections detected from October 1988-2002 are HIVIAIDS carriers. Drug addicts using injections that are infected with $\mathrm{HIV}$ in 1988 is $0.14 \%$, while in 1990 the percentage increases to $5.1 \%$ and $16.5 \%$ in 1993 . These infection figures rose to 19.5\% in 1998 (Sharol Lail, 2001).

There are several theories that can be used to give an explanation on the origin of this problem, such as the theory of functionalism, conflict theory, subculture theory, the theory of interactionism, and various other theories. According to Yusof W. (1994), these theories are real and formulated as a result of certain resources and causes. Therefore, we need to identify main "roots" that causes an individual to involve in drug addiction behavior and strategies to overcome this illness.

Drug addiction can be equated with other diseases such as fever, cancer and TB which starts from its own sources. The original source of drug addiction as perceived by Islam is caused by individual attitude resulting from impure heart. In other words, the main cause for drug addiction is largely due to malfunction of human's heart. Abd. al-Somad (no date) describes that the heart is considered as a king, while the human body as a state and limbs (hand, foot, eye, etc.) are soldiers. This theory is derived from the saying of the Prophet Muhammad (peace be upon him) which reads as follows:

'Truly in the body of the son of Adam (humans) there is a good piece of meat when it is good, it would let all members of his body to be good and when it is evil, the entire body is evil. It is nothing else than heart " (Bukhari and Muslim)"

Based on this saying, heart can cause and influence human attitude, be it good or bad. Moreover, Yusof W. (1994) added that negligence of man's heart (soul) from remembrance of Allah is the cause of personality collapse which leads to mischievous and forbidden activities including drug addiction.

In PRI, the practice of remembrance to Allah is considered as one of the methods for drug rehabilitation process. It can be divided into two namely aloud (jahar) and silent (khafi) which is performed on a regular basis after prayers. Aloud remembrance, the remembrance of God with specific words of faith, is pronounced with tongue with specific conditions, manners and methods. Among the conditions of this remembrance is sermon of a teacher (talqin) or its designee, ablution, vibrant voice and a powerful shot into the heart. The implementation of remembrance is not just spoken, but also instilled strong confidence in people's heart, good behavior and practices. It is practiced at all times after the completion of a number of prayers for at least 165 times. Silent remembrance, on the other hand, is the remembrance of Allah's name grown and filled in the hearts and feelings of a person's heart until Allah's existence is realised. It is also performed with certain conditions, manners and methods. It is implemented at all times after the completion of the prayers and aloud remembrance (Adam, 2012). As a result, the feeling of closeness and sense of love and obedience to Allah through these two remembrances is indeed important to combat the passions and temptations of Satan that leads to drug addiction. Therefore, the investigation on the consistency practice of remembrance to Allah during drug rehabilitation treatment is relevant. 


\section{Materials and Method}

\subsection{Design}

This paper holds on to postulate that the aberrant behavior is caused by a damaged heart and it can only be cured through the practice of remembrance to Allah both aloud and silent methods. Thus, the frequency and consistency of remembrance can influence the healing process of an individual's heart and consequently prevent further involvement in social problems. This study aims to explore the consistency of the practice of remembrance to Allah among former and relapsed drug addicts. Data and information are collected using qualitative and quantitative approaches. In the former, a survey is conducted to 60 respondents from two Inabah Rehabilitation Centre in Kedah and Terengganu whereas the latter uses in depth interview with 10 key informants. The application of mix method is relevant to the study in order to validate and support the collected data.

\subsection{Sample}

The study uses purposive sampling technique where a survey is conducted on 60 respondents that includes two groups, namely the group of 30 former drug addicts who live in Terengganu and the group of 30 relapsed drug addicts who are undergoing rehabilitation at Pondok Remaja Inabah (the Inabah Rehabilitation Centre) in Kedah and Terengganu (PRI). From these respondents, 10 individuals are selected as key informants for an in depth interview procedure.

Data is collected using triangulation methods through structured and unstructured interviews, and observation. The data obtained are analyzed using qualitative method and supported by quantitative approach involving the use of descriptive statistics and statistical inferential to in the form of frequency distribution, percentages and The Mann-Witney $\mathrm{U}$ Test analysis.

\section{Results and Discussions}

\subsection{Socio demographic profile}

Overall, men represent the whole demographic respondents of the study. The majority of former drug addicts involved in this study are over 30 years old with marital status, while relapsed group are less than 30 years old and still single. Both groups still have their parents when using drug and are living with them.

In terms of socioeconomic status, the majority of both groups are relatively low which correlates with the level of education and nature of their employment. The majority of them are either on irregular working basis or working with family members. Inability of obtaining and securing certain jobs consequently lead their involvement in drugs. In terms of the level of addiction, $30 \%$ of the respondents are in a serious level of addiction (high and very high) with 16.7\% out of this figure are from relapse group. However, most respondents from the two groups remain at low and medium level of drug addiction. The majority of them voluntarily admitted into PRI for rehabilitation. Former drug addicts receive treatment and rehabilitation for a period of between one to two years while relapse receive less than a year treatment.

\subsection{Consistency of Aloud (Jahar) Remembrance}

The consistency of remembrance (zikir) refers to continuous performing remembrance for at least 40 days. Failing to execute continuous 40 days remembrance to Allah after night (tahajud) and obligatory prayers is classified inconsistent and ineffective. In the consistency of aloud remembrance, the study found that almost all the former addicts perform it consistently while their rehabilitation treatment in the PRI, and only one respondent who practices this remembrance method consistently for three months. Nearly half of the relapses, however, perform aloud remembrance for the whole rehabilitation period at the PRI. One person continuously performs it for five months of rehabilitation period and the remaining patients perform it for 40 days. Besides, the descriptive analysis found that $83.3 \%$ of the former drug addicts always perform consistent aloud remembrance and the rest (16.7\%) often perform this remembrance method. However, $70 \%$ of relapsed drug addicts always perform it consistently, while $10 \%$ frequently perform whereas $20 \%$ never consistent in performing this remembrance while they were in the PRI.

Overall, these data show that there are differences between the two groups. However, the differences in these two groups are insignificant. This can be seen more clearly when comparing the Mann-Witney $U$ Test analysis where results prove there was no significant difference between these two groups $(z=-1500 ; p<0134)$. Moreover, mean score of the 
two groups were not significantly different with a mean score of 33.00 for former drug addicts, while 28.00 for the relapse.

\subsection{Consistency of Silent (Khafi) Remembrance}

The study found that nearly all former drug addicts consistently perform silent remembrance while their treatment at the PRI, and only one respondent who carries this method of remembrance consistently for three months. In the relapsed group, half of them consistently perform silent remembrance for 40 days, only one respondent perform it for five months whereas the remaining practice it for the whole rehabilitation period at the PRI. Descriptive analysis found that nearly all former drug addicts often (86.7\%) perform consistent aloud remembrance and $13.3 \%$ always perform it. Sixty seven percent of the relapse always performs aloud remembrance consistently, $10 \%$ often perform it, $3.3 \%$ very rare and $20 \%$ do not consistently perform this remembrance method during their treatment at the PRI.

Those respondents provide several factors contributing to their capability to consistently perform aloud remembrance. Among those factors are continuous supports from guider at the rehabilitation centre, motivation from close friends, the ability to feel the impact of remembrance that they believe provide strength and peace to the soul and the belief that the soul is always clean through practicing silent remembrance consistently. On the other hand, the majority of them admit to the fact that their inability to wake up after midnight to perform night prayer and remembrance practice consequently contribute to ineffective treatment. In other words, sleeping habit limits their participation in PRI activities including the practice of silent remembrance. Based on in site observation among drug addicts, some respondents were found asleep when aloud and silent remembrance is performed. This situation is considered a significant contributing factor that prevents this group from consistently perform silent remembrance.

The difference of consistency between the two groups may be influenced by respondent's own background. The way how respondents were admitted to the centre also influence their motivation of performing remembrance. The study found that respondents who voluntarily entered the PRI perform more consistent remembrance. On the other hand, respondents who were forced or by means of deception by family members during admission to the centre, often were seen skipping performing remembrance practices. This may due to their dissatisfaction with family effort of admitting them to the centre without their consent. In a more serious scenario, they ultimately left the centre before the minimum period of rehabilitation. This finding is consistent with a study by Norliza Abdullah (2000) who found that the way of entry can also influence respondents' motivation to understand and follow rehabilitation program in the PRI. Respondent voluntarily entering the centre shows high and consistent commitment of remembrance practice. This result was also supported by a study of Nor Aini, Siti Hayati and Malini (1987) who indicated that trainees who enter the Bukit Mertajam centre forcibly did not follow rehabilitation programs successfully and experienced difficulty in changing behavior. This is due to their insincerity while performing remembrance which causes little effect in rehabilitation program.

In terms of duration of remembrance, the study found that former drug addicts undergo one to two years rehabilitation period, while the relapse undertake only between two months to one year. It is proven that the longer they follow the treatment, the higher their tendency to perform the practice of remembrance. In other words, frequent and quantity of remembrance practice leads to consistent practice of aloud and silent remembrance. The relapsed drug addicts, however, perform lower practice of remembrance. It can be assumed they could not adapt to the new environment and treatment method in PRI. This finding is consistent with a study by Mahmood (1995) who reported that drug addicts who received several months of treatment in rehabilitation centre were found to have higher levels of selfesteem and produced more positive view.

In a different scenario, the process of remembrance is a process of socialization among the respondents. According to Rohana (1996) socialization is a social process through which the individual to become a member of a group to learn the culture of the group and its role in the group. For the early stage respondents of PRI, they are not entirely acceptable to the practice of remembrance. They prefer to be alone rather than performing a mass remembrance practice. However, when they had been in the centre for quite some time, understand the remembrance very well, and become close with few patients in the PRI, relationship and social support among them increases. The process of undergoing remembrance practice can be implemented more easily and consistently. The longer they are undergoing rehabilitation at the PRI, the more practice of remembrance they are able to perform.

Moreover, regular practice of remembrance, large quantity and consistency can change drug addiction habit because remembrance can purify heart from various diseases. When heart is always filled with the remembrance of Allah, the connection to Allah is constantly preserved and its influence on internal attitudes will become more effective which produce positive attitude.

The ability and strength of remembrance in developing individual's character and morality is undeniable. In a similar principle, the effectiveness of treatment and drug rehabilitation program at PRI is largely due to a regular, large 
quantity and consistent remembrance and at the end this practice will be able to serve as internal control to treat drug addiction. Therefore, the level of consistency in the practice of remembrance is important as it can lead to the existence of internal controls to practitioners which will prevent re-engagement in any activity of drug abuse.

\section{Conclusion}

In recognition that the practice of remembrance of Allah is a factor that contributes to the successfulness of drug rehabilitation process, a study concerning the consistency of remembrance practice among drug addicts was undertaken. This study intended to identify the consistency level of remembrance practice on drug rehabilitation treatment. The former and relapsed drug addicts at the Inabah Rehabilitation Centre in Terengganu and Kedah were chosen as respondents of the study.

Based on survey, interview and in site observation, the consistency of remembrance practice between the two groups of drug addict is very significant and has become an important contributor to the success of drug addiction treatment. The findings show that the former drug addict successfully cured of drug addiction as they undergo the practice of aloud and silent remembrance consistently. The study also proved unsuccessful and relapsed addicts is incurable because they are not consistent in the practice of remembrance during the treatment. In addition to quantity and consistency of remembrance practice, duration of the treatment and the willingness to undergo treatment also contributed to the effectiveness of the drug rehabilitation process. This combination of factors makes the process of drug rehabilitation treatment becomes easier and effective.

\section{References}

Abd. Somad al-Palimbangi. (no date). Sira al-salikin. Bangkok: Muhammad al-Nahdi Wa Auladihi.

Adam, F., Wan Ahmad, W.I. \& Abdul Fatah, S. (2011). Spiritual and traditional rehabilitation modality of drug addiction in Malaysia. International Journal of Humanities and Social Science, 1(14), 175-181

Adam, F., Wan Ahmad, W.I. \& Abdul Fatah, S. (2012). Frequency of zikir (remembrance to Allah) in drug rehabilitation process among Malay society. International Journal of Humanities and Social Science, 2(3), $92-95$

Chuah Mooi Kim. (1990). Keyakinan diri penagih dadah: hubungannya dengan sokongan sosial dan faktor demokrafi (Latihan Ilmiah), Bangi: UKM.

Jamaluddin, Mohd. Khairie, Zaheruddin \& Subri (2000). Tinjauan persepsi keluarga penagih dadah terhadap pusat serenti berdasarkan faktor demografi. Prosiding Seminar Jabatan Kerja Sosial, UUM.

Mahmood, N.M. (1995). Pemulihan penagihan dadah modaliti serenti: cabaran masa kini, Prosiding Seminar Kebangsaan Gejala Kerja Sosial. Sintok: UUM.

Noraini, M.N., Siti Hayati, A., \& Malini, R. (1987). Kajian kes mengenai profail psikologi penagih dadah. Kajian Malaysia, 5(2), 87-102.

Norliza Abdullah. (2000). Keberkesanan teknik zikir dalam rawatan dan pemulihan dadah di Pondok BELIA Inabah, Kampung Sungai Ikan, Kuala Terengganu, Terengganu (Kertas Latihan IImiah). Sintok: Sekolah Pembangunan Sosial, UUM.

Rohana, Y. (1994). Perbomohan dan peranan dalam pemulihan penagihan dadah, Jurnal Kebajikan Masyarakat, 1(17), 27-37.

Rohana, Y. (2010). Asas sains sosial dari perspektif sosiologi. Kuala Lumpur: Dewan Bahasa dan Pustaka.

Sharol Lail S. (2001). Pertahanan badan, Kuala Lumpur: Dewan Bahasa dan Pustaka

Spencer, C.P. \& Navaratnam, V. (1981). Drug abuse in East Asia. Kuala Lumpur: Oxford University Press

Yusof W. (1994). Inabah suatu metoda penyadaran, Singapura: Bawean Putra Sepaktakraw Club.

Wan Mahmood Pawanteh. (1988). Penyelarasan jentera perlaksanaan dalam bidang peranan dan penglibatan masyarakat dalam usaha membenteras dadah. Konvensyen PEMADAM Kebangsaan, Ipoh: PEMADAM. 